\title{
Languages of the Heart: The Biomedical and the Metaphorical in American Fiction
}

\section{Citation}

Oldfield, Benjamin J., and David S. Jones. 2014. "Languages of the Heart: The Biomedical and the Metaphorical in American Fiction." Perspectives in Biology and Medicine 57 (3): 424-442. doi:10.1353/pbm.2014.0029.

\section{Published Version}

doi:10.1353/pbm.2014.0029

\section{Permanent link}

http://nrs.harvard.edu/urn-3:HUL.InstRepos:27726996

\section{Terms of Use}

This article was downloaded from Harvard University's DASH repository, and is made available under the terms and conditions applicable to Open Access Policy Articles, as set forth at http:// nrs.harvard.edu/urn-3:HUL.InstRepos:dash.current.terms-of-use\#OAP

\section{Share Your Story}

The Harvard community has made this article openly available.

Please share how this access benefits you. Submit a story.

\section{Accessibility}




\title{
Languages of the Heart
}

\section{the biomedical and the metaphorical in American fiction}

\section{Benjamin J. Oldfield* and David S. Jones $\uparrow$}

*Departments of Medicine and Pediatrics, Johns Hopkins University School of Medicine, Baltimore.

$\dagger$ Faculty of the Arts and Sciences and Faculty of Medicine, Harvard University, Cambridge. Correspondence: Benjamin J. Oldfield, Department of Medicine, Johns Hopkins University School of Medicine, 1800 Orleans Street, Baltimore, MD 21287.

E-mail: boldfie1@jhmi.edu.

\begin{abstract}
The role of heart disease in American fiction has received less attention from scholars of literature, history, and medicine than have portrayals of tuberculosis, cancer, or HIV/AIDS, despite the fact that heart disease topped mortality charts for most of the 20th century. This article surveys manifestations of coronary artery disease in popular works of 20th-century American fiction to trace how authors and their protagonists grappled with the disease while knowledge of pathophysiology and therapeutics evolved. Countering Susan Sontag's mechanistic vision of patient encounters-where disease is absent of metaphor-we pair popular fiction with concurrent historical analysis to show that the proliferation of technological narratives of cardiac therapeutics could not displace the deeply symbolic nature of characters' encounters with heart disease. Because of the limited ability of the biomedical narrative to convey the meanings of disease and treatments, doctors and patients need to communicate through the rich possibilities of metaphor.
\end{abstract}

Two American stories, separated by 150 years, climax with the sound of a beating heart. In Edgar Allan Poe's 1843 "The Tell-Tale Heart," the rhythm of the guilty heart compels the narrator's confession: "It 
was a low, dull quick sound ... 'Villains!' I shrieked, 'dissemble no more! I admit the deed! - tear up the planks! — here, here! — it is the beating of his hideous heart!"” (191) In Thom Jones's 1995 "Ooh Baby Baby," the drama arises from Dr. Moses Galen's recognition of his own fatal dysrhythmia: "Suddenly it felt like a flock of wing-beating chickens had been rousted from his chest, making him light-headed. Jesus! Ventricular fibrillation" (145). Despite all that came between their writing — changes in social context, narrative conventions, medical theory, and medical practice — the stories remain linked by a dramatic device that demonstrates the persistence of the image of the heart in American thought and fiction.

The role of the heart, and of heart disease in particular, in American fiction has received less attention from scholars of literature, history, and medicine than have portrayals of tuberculosis, cancer, HIV/AIDS, or mental illness, despite the fact that heart disease topped mortality charts for most of the 20th century. Coronary artery disease (CAD) alone caused one-third of American deaths in the decades that followed World War II. Over the one hundred years that CAD has dominated mortality, it has been portrayed regularly in the works of writers from Kate Chopin to Philip Roth, sometimes entering stories in a brief but decisive role—as in Vladimir Nabokov's Lolita or Jhumpa Lahiri's The Namesake—and sometimes as a pervasive hinge on which the book's plot depends, as in John Updike's Rabbit at Rest. By surveying manifestations of CAD across these and other popular works, we trace how authors and their protagonists grapple with the disease as knowledge of pathophysiology and therapeutics evolved.

Fictional accounts of the CAD experience in American fiction can be parsed into two therapeutic eras. Characters before the 1960s had few treatment options: they had to conform their lives to the dictates of the disease. Characters after that time faced the mixed blessings of the proliferating pharmacological and surgical treatments of CAD and heart failure. Narratives from this second era, rich with descriptions of angioplasty and bypass surgery, demonstrate the potential for mastery over heart disease through prevention and treatment. However, the stories' protagonists are often unsatisfied with, and even resentful of, the impact of cardiac therapies on their lives. The proliferation of reductionist and technological narratives of cardiac therapeutics could not displace the deeply symbolic nature of 
characters' encounters with heart disease. Treatments, despite their potential efficacy, are revealed to carry significant cost for these protagonists, forcing them to choose between a medicalized life and a life they consider worth living.

\section{Metaphor, Narrative, and Coronary Artery Disease}

Over the last three decades, scholars of the humanities and social sciences have argued that metaphor and narrative are the principle tools with which human beings make sense of their experiences, and this understanding has been directly applied to science and medicine (Hanne 2011). In Metaphors We Live By, George Lakoff and Mark Johnson (1980) showed the pervasiveness of metaphor in all forms of discourse and suggested that our "conceptual system in terms of which we both think and act is fundamentally metaphorical in nature" (3). [AU: Please provide page numbers for direct quotes, here and below. See highlighting. Thanks. SR] Roger Schank (1990) and others have asserted that narrative is the principal faculty by which humans interpret the world. Schank claims that "storytelling and understanding are functionally the same thing" (24). Since these and other seminal works appeared, narrative studies and metaphor studies have extended their reach to disciplines such as law, economics, and medicine, examining how these devices influence the everyday practice of those disciplines (Charon 2006; Hanne 1999). [AU: Please confirm date: 1999 in References. SR]

Because biology operates at the edge of what is known about living systems, metaphor and storytelling are important tools for meaning-making in what Yair Neuman (2005) calls "the boundary between organization and disorganization," the space that characterizes this field of inquiry (321). For medicine, a practical and interpersonal application of biology, narrative, and metaphor are useful tools in several clinical exchanges. They provide patients a medium for making sense of their illness experience and conveying this experience to care providers. Likewise, they offer tools to care providers for explaining diagnoses and motivating adherence to treatment plans. And they give structure to the arguments epidemiologists and public health officials use in seeking health-care reform. Rita Charon (2006), who directs Columbia University's Program in Narrative Medicine, describes patients, caregivers, 
and epidemiologists all as obligate storytellers in these exchanges.

Rationally or not, patients often use stories to designate causality in illness. Consider, for example, Jerome Groopman's (2005) discussion of a case of a woman who attributes her diagnosis of cancer to her marital infidelity. Working with this self-wrought narrative is a necessary step for this woman's physicians in establishing a therapeutic alliance with her and promoting shared decisionmaking. Likewise, with metaphor, physicians have long recognized a clinical significance to the figurative language used by patients to describe their symptoms. Pulmonologist Richard Schwartztein has linked descriptors of respiratory distress ("air hunger," "chest tightness," and the like) to diagnostic categories with validated precision (Binks et al. 2002; Moy et al. 1998).

Care providers are called upon not only to be thoughtful listeners to the narratives and metaphors their patients use; they also must be competent storytellers themselves. Since the advent of the biopsychosocial model (Engel 1977), how storytelling and metaphors contribute to compassionate and culturally sensitive care has been an area of active research for framing interactions between patients and caregivers (Fuks et al. 2011; Good 1994). This focus is manifest, for example, in proposals that physicians use their patients' narratives and metaphors in their medical records to account for their reasons for seeking medical care and that psychotherapists work actively with the emotional- laden metaphors that their patients use (Angus and Mio 2011; Schleifer and Vannatta 2011).

Despite their power for providing answers to the questions of who gets certain diseases, why they do, and how the stories of their diseases might end, disease narratives and medical metaphors have also been critiqued for being reductionist and for generating bias. Take, for example, the metaphor of the human body as a machine. It is a metaphor that has seen several iterations, from Descartes's "body as clock" theory of the 17 th century, to the 19 th century's notion of the nervous system as telegraphic system, to the 20th-century's likeness of the brain to a computer (Hanne 2011). Unsurprisingly, these associations have met considerable criticism. For instance, in The Woman in the Body (1987) and Flexible Bodies (1994), Emily Martin traces multiple ways that metaphor influences the communication of scientific and medical ideas to patients and popular audiences, often burdening them with destructive 
social values and judgments. Susan Sontag's analyses of the metaphors of tuberculosis, cancer, and HIV/AIDS have been especially influential. In Illness as Metaphor (1978) and AIDS and Its Metaphors (1989), she catalogued examples of the metaphors that epidemics accumulated, and of the harms these perpetrate on people with the diseases. Even though she understood that metaphoric thinking was an "ageold, seemingly inexorable, process," she still encouraged, in AIDS and Its Metaphors, a world in which disease would be freed of its "loaded meanings and misleading metaphors" and managed as a mechanical problem by physician-technicians. She found this vision "liberating, even consoling" (182). [AU: Please clarify which Sontag essay is being quoted in each case here. Thanks. SR] Particularly for those diseases whose causes remain unclear, which do not "knock before entering" (for Sontag, tuberculosis in the 19th century and cancer in the 20th), the etiologic void becomes a vacuum for fantasy to enter. Illness becomes less a disease and more a prescribed state of being that is limiting and judgmental of patients.

Significant developments in medical theory and practice since the 19th century-central to Sontag's mechanistic vision-have, surprisingly, worked at cross-purposes with this vision. In the 18th century it had been possible for patients to know nearly everything that physicians knew about their diseases: the symptoms, etiologic theories, and treatments. By the late 20th century, however, doctors increasingly diagnosed patients with asymptomatic diseases based on laboratory or imaging analyses. Patients had to be tested and then told that they had a disease. As more people understood their bodies through means external to their own experiences, metaphor and narrative techniques took on clinical significance as means of conveying the complexity of medical science to patients. Some patients, as seen in Anatole Broyard's (1992) critique of Sontag, reveled in disease meaning and metaphor, seeing it as essential to their passage through disease. Others have chosen to investigate which (and whose) categories of metaphor, which stereotypical narratives, are most instructive for patients' imaginative course through illness (Belling 2011; Holmes 2004).

Consider the role of diagnostic technology in CAD. An electrocardiogram differentiates cardiac angina from anxiety, heartburn, and other causes of chest pain. Coronary angiography provides images of the arteries and their plaques that then motivate, and sometimes obligate, therapeutic interventions, 
especially angioplasty. CAD is typically explained as a plumbing problem. After all, coronary arteries function as pipes that convey blood to the muscles of the heart. Atherosclerotic plaques, which accumulate like the gunk seen in the pipes of old houses, obstruct this flow. Cardiologists and surgeons intervene, as plumbers might, by cleaning the pipes or bypassing the obstructions, restoring blood flow to diseased tissue (Jones 2013; Mount Sinai Hospital 2011; Sanghavi 2007). [AU: Please confirm date: 2010 in Refs. SR] This accessible vision has an enormous impact on cardiac decision-making. Clinicians today, for example, speak of an "oculostenotic reflex," in which significantly narrowed blood vessels, once seen during cardiac catheterization, obligate intervention (Lin and Dudley 2014). This despite a lack of evidence that such an intervention will improve symptoms or mortality in these patients. The problem is that coronary arteries are not pipes: they are living tissues of far greater complexity. The plumbing metaphor over-simplifies the pathophysiology, misdirects patient and physician attention, and contributes to substantial overuse of coronary angioplasty in the United States (Goff et al. 2014; Rothberg et al. 2014).

It is not possible to write a comprehensive portrait of any particular disease in American fiction. There is no mechanism that can identify every work in which heart disease played a prominent role. We surveyed popular American fiction over the last century using New York University's Literature, Arts, and Medicine Database (1993-2015), a well-known database for the medical humanities, as well as informal discussions with our colleagues in literary fields. We identified many works by authors of varying stature, but assume that other works exist that might offer different perspectives. Our sample veered towards white men, with respect to both the authors and their protagonists. We do not assume this outcome to be a product of our search process. Instead, it likely reflects widespread assumptions about who was at risk for heart disease in the 20th century. Another review 50 years hence will presumably find more diverse actors and authors, as the epidemiology of the epidemic continues to shift and popular understanding catches up.

The resulting bibliography serves to map the evolution of metaphors and narrative patterns alongside the changing diagnostic and therapeutic landscape of heart disease. As Broyard (1992), Holmes 
(2004), Belling (2011), and others have argued, Sontag's vision is a hazardous stopping point for narrative and metaphor studies in medicine. Here, the changing landscape of heart disease provides a dynamic case study where imaging and other technology has allowed for the potential for mastery over diagnosis, treatment, and prevention. Less and less is cardiac disease a pathology that “doesn't knock before it enters." As medical understanding and therapeutics have evolved, we are witnessing a dialogue between burgeoning technology and metaphorical thinking. This exploration is useful not only for scholars of literature and history interested in the changing meanings of disease, but also for clinicians interested in improving patient-caregiver communication and implementing effective shared decisionmaking (Sepucha and Mulley 2009; Sopory 2005; Sopory and Dillard 2002).

\section{Emotional Hearts}

The heart as metaphor has long been a fixture of European prose and poetry (Hillman 1981). William Harvey (1628), the English physician credited with describing the circulation of blood, not surprisingly emphasized the heart's importance. He called it "the first principle of life and the sun of the microcosm" that "performs his office for the whole body by nourishing, cherishing, and quickening, being the foundation of life and the author of all things" (76). This prioritization carried into English culture more broadly. For Robert Erickson (1997), who surveyed 17th- and 18th-century English literature for heart imagery, heart is "the single most important word referring both to the body and mind" (11). Erickson traces its impact from the 858 occurrences of heart in the King James Bible to Satan's assault on Eve's heart in John Milton's Paradise Lost. Kristie Blair (2006) explores the continuing relevance of the heart in Victorian poetry. As the heart received increasing medical attention in the 19th century, poets explored the dual meanings of the heart as an organ of specific pathology and as the seat of love, spirituality, and other emotions. Broken hearts figured prominently. Emotional strain, especially from unrequited love, once internalized by the heart could be lethal. While a modern cardiologist might be reluctant to grant such credibility to a "broken heart," this danger remained an active part of folk and medical physiologies throughout the 19th century (Duffin 2002). 
Scholars have argued that the heart lost its cultural primacy in the late 19th century. In Matters of the Heart, Fay Bound Alberti (2010) explores the dynamic meanings of the heart in 18th- and 19thcentury Britain and describes its fall from prominence. With the rise of neurology and psychiatry in the late 19th century, the brain displaced the heart as the organ of greatest interest to culture and literature. If Alberti is correct, this shift might provide a partial explanation for Sontag's observation that the heart is not an interesting organ. Sontag saw little promise in explicating the meanings and metaphors of heart disease. Even as she found rich meanings in tuberculosis and cancer, in Illness as Metaphor she dismissed heart disease as a "failure that is mechanical" and exempt of stigma. Unlike HIV/AIDS or cancer, there is "nothing shameful about a heart attack" (7). [AU: Please clarify which Sontag essay is quoted here. SR]

One might, then, expect heart disease to occupy a metaphor-free zone, a space where technical mastery prevails over emotion and meaning in disease narratives. Certainly, cardiologists felt increasingly in command of the heart as the 20th century progressed. Boston cardiologist David Spodick celebrated in 1978 how physicians "can make the heart perform tricks, with everything from simple bedside maneuvers to sophisticated pharmacologic and physiologic interventions" (871). However, a metaphor-free zone never became manifest. The rich meanings of heart disease survived both the brain's rise to prominence in popular culture and physicians' claims of increasing technical mastery over the heart.

The heart, for instance, retained its status as an emotional organ at the turn of the century. In Henry James's “The Turn of the Screw” (1897), the heart plays a traditional role. It is the object of emotional turmoil when Miles, the boy the haunted governess cares for, "set my heart aching with such a pang as it had never yet known" (74). Miles dies in an ambiguous climax: "he uttered the cry of a creature hurled over an abyss . . . at the end of a minute I began to feel what it truly was that I held. We were alone with the quiet day, and his little heart, dispossessed, had stopped" (103). Miles's heart provides testimony to his death without revealing the nature of his demise. The heart, for James, had the capacity to ache with emotion, and its possession, or dispossession, could kill.

In other stories, heart disease, like tuberculosis, was associated with aesthetic suffering and mysterious purity. Consider James's Wings of the Dove (1902). The story revolves around an heiress with 
an unnamed terminal illness. The diagnosis did not matter to James. As he described in the book's preface, his "idea, reduced to its essence, is that of a young person conscious of a great capacity for life, but early stricken and doomed, condemned to die under short respite, while also enamoured of the world" (3). Her plight is attributed to "some obscure cause" (115). Given the prominence of tuberculosis in literature from this period, many readers, including Sontag, have assumed that tuberculosis was Theale's diagnosis (Mercer and Wangensteen 1985; Sontag 1990). But ambiguity is one of James's objectives here: in his Notebooks (1981), James describes his desire for his heroine to be "condemned to death (by consumption, heart-disease, or whatever)" (169). His willingness to leave the disease nameless implies a symbolic likeness between tuberculosis and heart disease, which both could be plausible explanations for Milly's beatific descent into a pale waif.

In contrast to its passing appearance in these two stories, the heart plays a decisive role in Kate Chopin's "The Story of an Hour" (1894). Heart disease sets the tone in the opening sentence: "Knowing that Mrs. Mallard was afflicted with a heart trouble, great care was taken to break to her as gently as possible the news of her husband's death" (198). Though her friends had expected her to react with grief, Mrs. Mallard has a surge of adrenaline for a different reason. In a move that shocked readers in the 1890s, Mallard experiences liberation at her husband's death: "Her pulses beat fast, and the coursing blood warmed and relaxed every inch of her body" (199). But when she learns that rumors of his death had been false, she drops dead. Chopin describes how the other characters interpret her death: "When the doctors came they said she had died of heart disease — of joy that kills" (200). Although the doctors erred in their diagnosis of joy, it was indeed an emotion — despair over her lost liberation — that broke her heart. Regardless of the vector of emotion, its intensity kills.

\section{Laboring Hearts}

Over the early decades of the 20th century, the nature of heart disease in America changed. Early in the century, when the bills of mortality listed "heart disease" as a cause of death, it might have meant many things. William Osler, for instance, devoted 103 pages to diseases of the circulatory system in the 1892 
first edition of his influential Principles and Practice of Medicine. He covered pericarditis, endocarditis, valvular disease (the largest section, and mostly rheumatic), cardiac hypertrophy, myocardial disease, neuroses of the heart, and, only briefly, angina pectoris and arteriosclerosis. The burden of heart disease, however, shifted steadily between then and 1950, with rheumatic heart disease becoming less common as CAD rose to prominence. Medical narratives of CAD represented the disease as a disease of civilization, the result of industrialization and rising standards of living (Aronowitz 1998; Rosenberg 1998). It was initially seen as a disease of male elites, especially doctors. Osler, in his 1910 account of angina pectoris, described it as the "morbus medicorum" (698). A half-century later, cardiac surgeon Donald Effler (1968) explained how CAD was "so common among professional people, executives and men in public office" that it could "cripple the nation" (000). Despite this focus on elites, there was gradual recognition that the disease affected all people. One series of 800 cases of coronary occlusion in New York City included 337 laborers, 221 housewives, and 114 businessmen, a broad cross-section of the city's population. The authors concluded that the disease was "no respecter of poor or rich, laborer or sedentary worker" (Master, Dack, and Jaffe 1939, 435).

The presence of CAD in American fiction at this time suggests a growing familiarity with these narratives, especially of laborers struck down as they struggled to get by in a competitive economy. In Willa Cather's "Neighbour Rosicky" (1928), heart disease casts a pall over the story. Rosicky, a hardworking Czech immigrant, struggles to farm land that is less fertile than his neighbor's. This effort leaves him tired and short of breath. When he presents to his physician, he finds that Dr. Burleigh, like other doctors in the 1920s, has little to offer patients with heart disease. He does, however, warn Rosicky about the danger of exertion. Rosicky's disregard for this treatment regimen has foreseeable consequences. On bringing his horses back to the barn, “the pain had come on so sharp in his chest that he didn't try to take the harness off .... The cramp in his chest was shutting him up like a jack-knife" (63). The next day the pain returns. Before he could get help he dies, presumably of a heart attack (69).

Other sources from literature, music, and folklore in the early 20th century tell similar stories of heart disease arising from the struggles of men to keep up with an increasingly competitive economy. 
Take John Henry, the labor movement's icon and a symbol of racial solidarity (Nikola-Lisa 1998). As Bruce Springsteen (2006) tells it, he "worked so hard it broke his heart." Or consider "Desolation Row" (1965), Bob Dylan's anthem to urban chaos, where the "superhuman crew" of factory workers all wear a "heart attack machine," a perverse display of the fate of the working conditions in urban America. In Billy Joel's “Movin' Out” (1977), New York immigrants who attempt to earn enough to achieve a comfortable life will end up with an emphatic "heart attack-ack-ack-ack-ack-ack."

A heart attack may have been identified as a disease of white-collar America, but it was also the grim reward for those working-class individuals who attempted to ascend the economic ranks or oppose modernization. Neighbor Rosicky, John Henry, and Bob Dylan's factory workers all link heart disease to a valiant, if futile, struggle to realize an unreachable American dream. This active, heroic suffering contrasts with the passive suffering seen in the female protagonists in James and Chopin, and it suggests an evolving metaphor. It is at once an iteration of the traditional symbol of the heart (these characters are the courageous ones who confront adversity) and a new image rooted in the changing biomedical understanding of the heart, which was thought to be adversely affected by stressful lifestyles.

Linking heart disease to a failure of attainment of an American dream accessible primarily to white men, these and other works of fiction reinforced gendered assumptions about heart disease in America. Assuming that our sample of American fiction is representative, nearly all of the protagonists (and a majority of the authors) are men. The author bias could reflect a number of factors: who was writing fiction, who received the most attention, and who wrote about heart disease. The bias in protagonists almost certainly reflects the gendered understandings of heart disease in 20th-century America, not just in popular cultural but in medicine as well. Historian of medicine Cara Kiernan Fallon (2014) has traced the relationships between gender roles and cultural references to heart disease, and the ways in which these conceptions contributed to the marginalization of heart disease in women. Even after heart disease had been recognized as the leading cause of death for American women, prominent physicians continued to frame it as a disease principally afflicting men. If women had a role in heart disease, it was simply to support their ailing husbands. For instance, in 1966, Boston cardiologist Paul 
Dudley White and Samuel M. Fox, chief of the heart disease control program of the U.S. Public Health Service, contributed to an article in the Youngstown Vindicator about "tips for wives interested in protecting their husbands' hearts" (Blakeslee 1966). Their advice perpetuated familiar gender roles: “Get your husband to go out for a walk with you in the evenings," and "Serve and eat a moderate diet." It is no surprise that the one exception in our sample is Kate Chopin's Mrs. Mallard. How fitting that Chopin used heart disease to strike down a woman who so emphatically rejected gendered social expectations.

\section{Modern Hearts}

The years after World War II saw the full emergence of the epidemic of CAD. During the second half of the century, heart disease manifested in American fiction in several narrative forms that increasingly drew on contemporaneous understandings of its pathophysiology alongside its traditional symbolism.

Consider Vladimir Nabokov's Lolita (1955). The book's Foreword, which explains how the manuscript supposedly came into the publisher's possession, explains casually that “'Humbert Humbert,' their author, had died in legal captivity, of coronary thrombosis, on November 16, 1952, a few days before his trial was scheduled to start" (3). Although this may well be the first mention of coronary thrombosis as the mechanism for a heart attack in a work of American fiction, most of the novel invokes older emotional meanings of the heart. Early in the story Humbert gives his "nymphet," Dolores, whom he nicknames Lolita, an apple. "She grasped it and bit into it, and my heart was like snow under thin crimson skin" (58). After an outdoor sexual encounter, two children walk past and see Lolita weeping in his arms; the surprise causes "one of those jolts that have ended by knocking my poor heart out of its groove" (169). When the narrative engages directly with the diagnosis, Humbert is dismissive. In an emergency room after a drunk driving crash, he described how alcohol strengthened his "tricky but not necessarily diseased heart" (247). He later manages to walk for miles during his final quest to recover Lolita and is reassured "that my heart is basically sound despite recent diagnoses" (281), differentiating the organ's emotional and biomedical functions.

In Jhumpa Lahiri's The Namesake (2003), CAD is employed for its unexpectedness. Early in the 
story, Ashoke must bear the unanticipated news to his wife of her father's death. He tells her "what Rana told him a few minutes ago, what Rana couldn't bear to tell his sister, over the telephone, himself: that her father died yesterday evening, of a heart attack" (46). Years later, Ashoke develops stomach pain and goes to a emergency room, where he is found to have a heart attack that proves fatal. His wife rejects the news: “'No, no, it must be a mistake,' Ashima says calmly, shaking her head, a small laugh escaping from her throat. 'My husband is not there for an emergency. Only for a stomachache"' (169). It hardly seems real as the doctor explains "something about a heart attack, that it had been massive, that all attempts to revive him had failed" (169). The disease was a credible means of killing characters without any foreshadowing, a reflection of the all too common, yet dramatic, presence of CAD in late 20th-century American society. Lahiri's narrative also reflects the growing realization by the end of the century that heart disease had spread beyond the United States, Europe, and industrialized West to affect people (though again, with a focus on men) in India and other emerging economies.

In other stories CAD is a lingering and progressive malady. Marilynne Robinson's Gilead (2004) tells how 77-year-old John Ames, a Congregational minister, lives his life after learning that he is dying from CAD: “And now they say my heart is failing. The doctor used the term 'angina pectoris,' which has a theological sound, like misericordia" (4). Gilead freely mingles physical and spiritual meanings of the heart and heart disease. Like so many other women and men in postwar America, Ames sees CAD as the inevitable accompaniment of aging. Although his wife hopes that the doctor is wrong, Ames is resigned: "at my age there's a limit to how wrong he can be" (5). Among detailed descriptions of his anginal symptoms remains the symbol of the emotional heart. After a sleepless night, he says, "My heart is greatly disquieted. It is a strange thing to feel illness and grief in the same organ. There is no telling one from the other" (179).

Ames's writings offer a meditation on how to live graciously within the confines of terminal illness. Gilead takes place in 1956, a time when doctors still had little to offer CAD patients. Ames, a committed Calvinist, accepts that nothing can be done about his disease: "I have decided the two choices open to me are (1) to torment myself or (2) to trust the Lord. There is no earthly solution to the problems 
that confront me" (126). His heart, simultaneously the seat of emotion and the cause of his demise, could still be mundane: "Today there has been no hint of a thorn in my flesh, of a thorn in my heart, more particularly. The thump of my chest goes on and on like some old cow chewing her cud, that same dull endlessness and contentment, so it seems to me" (111). His matter-of-fact attitude startles his wife: "She's afraid I'll drop dead somewhere, and that's reasonable enough. It seems to me worse things could happen, actually, but that's not how she looks at it" (117). His hope, in the end, is a simple one, but one that again mixes the mechanical and the metaphoric: "I do hope to die with a quiet heart. I know that may not be realistic" (179).

\section{Treated Hearts}

Although Lolita, The Namesake, and Gilead all feature CAD prominently, in none of those narratives does treatment play a substantial role. Neither Ashoke nor his father-in-law ever had a chance for treatment. Humbert and Ames both died at a time when doctors had little to offer. The late 20th century brought rapid therapeutic innovation in many domains of CAD. Beginning in the 1950s, epidemiologists, exemplified by the Framingham Heart Study, refined their understanding of the risk factors at the root of

the epidemic. [AU: Add to References? SR] New diagnostic technologies gave doctors new precision. No longer confined to the tracings of an electrocardiogram, doctors could visualize a beating heart with catheterization and coronary angiography. Such exploits earned many cardiac specialists a portrait on the cover of Time magazine from the mid-1950s to the mid-1960s. (Time 1955, 1957, 1965, 1967). [AU: Not in References. If you don't wish to cite specific articles/covers, adding a more general statement like "from the mid-1950s to the mid-1960s" would probably suffice here. SR] Celebrities increasingly disclosed their own experiences, especially the drama of open-heart surgery. David Letterman, Regis Philbin, and Larry King all described how their lives were saved by coronary artery surgery. [AU: Add appropriate documentation to Refs? SR] These new capacities granted patients and doctors a new sense of agency against $\mathrm{CAD}$, an agency that American fiction embraced and ultimately challenged.

The most detailed portrait of CAD and its treatment comes with John Updike's Rabbit at Rest 
(1990). The final novel of a four-part series, the book completes the story of Rabbit Angstrom, the highschool basketball star turned car salesman, a man driven by libidinous impulses, consumed by complex relationships with his wife, lovers, and children. His sense of doom begins on the opening page as Rabbit waits for his son's family at a Florida airport, an event that triggers angina: "Little squeezy pains tease his ribs, reaching into his upper left arm" (15). The inevitable heart attack comes one afternoon while sailing with his granddaughter. Struggling to right a capsized Sunfish, "he feels crushed by his own limp load of slack muscle and fat and guts. The pain in his chest gathers to such a red internal blaze that he squeezes his eyes shut to blot it out" (135). At the hospital his wife asks the doctor what's wrong with Rabbit's heart. The doctor replies: “"The usual thing, ma'am. It's tired and stiff and full of crud. It's a typical American heart, for his age and economic status et cetera"' (166).

Unable to ignore his angina after the heart attack, Rabbit confronts the promise of medical technology. Prescribed nitroglycerin, he pops pills repeatedly. Offered a choice between bypass surgery and angioplasty, he chooses angioplasty but suffers a small heart attack during the procedure. His doctor recommends a follow-up catheterization, but Rabbit does not want to face a medicalized life: "life from here on in is apt to be insulting. Pacemakers, crutches, wheelchairs. Impotence" (475).

Philip Roth's Everyman (2006) tells a similar story of an aging protagonist, nostalgic for his lost vitality and libido, increasingly crippled by CAD. Death permeates the narrative, which begins at the narrator's own funeral. As with so many patient narratives of $\mathrm{CAD}$, his problem begins innocuously. Since he has eaten carefully, exercised regularly, and never smoked, he is dumbfounded when the electrocardiogram reveals severe CAD: "that he, with a lifelong regimen of healthful living, would end up as a candidate for cardiac surgery seemed preposterous. It was simply not how things were going to turn out” (42). Mirroring Roth's own experience with CAD (Roth 1991), his character survives a cardiac arrest and then quintuple bypass surgery. His life becomes a litany of vascular diagnoses and procedures, with atherosclerosis in his renal, carotid, and coronary arteries requiring stents, endarterectomy, and angioplasty, all of which have emotional consequences: "All these procedures and hospitalizations had made him a decidedly lonelier, less confident man" (79). A different medical procedure provides a 
metaphor for his experience — as he explains to his daughter, "he'd had 'an irreversible aesthetic vasectomy"' (103). One more attempt to fix his carotid arteries proves to be his last when his trust in the procedure comes up short: "He went under feeling far from felled, anything but doomed, eager yet again to be fulfilled, but nonetheless, he never woke up. Cardiac arrest" (162).

In Thom Jones's “Ooh Baby Baby" (1995), CAD is the mortal match for a successful physician himself. Moses Galen is a prominent cosmetic surgeon with a proclivity for younger women, fancy cars, and boxing. He doesn't let his symptoms derail his efforts at sexual intercourse, but "when it was over, he could hardly get any air and had to sit up on the edge of the bed, panting" (138). Working out at his punching bag the next morning, he develops stomach pain and conducts an informal stress test, "pushing himself to see if that damn pain in the chest was angina or a stomachache" (143). Punching harder, he soon gets his answer: "My God, it felt like a crowbar had been shot through his chest" (144). He connects the manner of his death to his prior career decisions. Wanting to die "with both guns blazing," he forces himself to keep hitting the bag: "He could have stayed in marvelous Africa and been a Hemingway man," but instead he had ended up in Los Angeles, catering to entitled celebrities, brought low by diabetes and CAD: "Fuckall! He fired away at the heavybag" (146).

\section{Regimen and Resistance}

In American fiction, $\mathrm{CAD}$ has been portrayed, on the one hand, as an acute attack striking without prior warning (as in Namesake) or despite prior treatment ("Ooh Baby Baby"). On the other hand, angina looms as a chronic presence in the lives of other characters, emerging forcefully at times of physical or emotional stress. When CAD is a chronic presence, the characters engage with medical therapy. Although physicians accumulated a therapeutic armamentarium over the 20th century, their patients did not always appreciate their efforts. Doctors advised patients to moderate the pace of their lives to decrease the demand on their hearts. In practice, such moderation stifles characters, takes away valued pleasures, and breeds resistance. In "Neighbour Rosicky," Doctor Burleigh tells Rosicky that he should avoid coffee, knowing that his advice is futile: “I've never yet been able to separate a Bohemian from his coffee or his 
pipe. I've quit trying'” (Cather 1928, 5). He also warns Rosicky to avoid heavy work and leave it to his five boys. Rosicky feels emasculated: “Though he was getting to be an old man, he wasn't an old woman yet" (25). The doctor in Gilead, meanwhile, warns Ames about even slight exertion. Ames feels guilty about defying this regimen. To his son, he writes "I must try to be more mindful of my condition. I started to lift you up into my arms the other day .... Then I saw your mother watching me with pure apprehension and I realized what a foolish thing to do that was" (Robinson 2004, 75).

For Rabbit Angstrom, consumed by his appetites for women and food, the regimen is an impossible challenge. Rabbit at Rest unfolds in episodes of temptation, surrender, and remorse. He tries to cut back on beer and junk food, and "each night after brushing his teeth he vows to but in the sunshine of the next day he's hungry again, for anything salty and easy to chew" (Updike 1990, 6). He becomes shameful after consuming a peanut brittle bar: “'Shit,' he says, in some embarrassment. 'I can't get away with anything any more" (6). He complains to his daughter-in-law about the strictures on his life: “"all they need to do is nail down the coffin lid. I can't run, I can't fuck, I can't eat anything I like'” (344). When he has sex with her the next night, he can't even enjoy it. While she was going for her second orgasm, he was "near to fainting with worry over joggling his defective heart" (354). Rabbit's passionsbasketball, playing with his granddaughter, love affairs - were his means of experiencing the world. When he chooses them over medical regimen, he restores himself even as he dies by doing so.

\section{Therapeutic Power and Ambivalence}

It is no surprise that patients and fictional characters alike have rebelled against the discipline demanded by preventive regimens for CAD. What may be surprising is their skepticism of doctors' targeted interventions. Rosicky, unimpressed by his doctor's advice and disappointed that he "“aint got no pills fur a bad heart,"” resigns himself to his fate: “'I can’t make my heart go no longer'n it wants to, can I, Doctor Ed?"' (Cather 1928, 5-6). Gilead's Reverend Ames is more compliant, but has little faith in his doctor. As he writes for his son, the doctors, when he was a child, "weren't good for much. It was poultices and cod liver oil and mustard plaster or splints or stitches. Or brandy" (Robinson 2004, 89). He is not 
impressed by his own doctor either, who recommends only rest and brandy for him. Lolita's Humbert is most explicit in his disdain: "I went to see 'our' doctor, a friendly fellow whose perfect bedside manner and complete reliance on a few patented drugs adequately masked his ignorance of, and indifference to, medical science" (Nabokov 1955, 94).

Stories set in the late 20th century exhibit a more complex therapeutic landscape, with protagonists dabbling in nitroglycerin, angioplasty, and bypass surgery. The stories acknowledge the potential of treatments to alter the course of illness. Jones (1995) describes Galen's confidence in his treatment: "I took aspirin and I've only got three years on this bypass. It should be good for ten. My cholesterol is one-five-eight and my HDLs are sixty-four. I can't have a heart attack"” (139). His faith, however, does not motivate close adherence to his diabetes regimen, and he dies in a self-destructive, help-rejecting binge. Roth's narrator (2006) is the most willing to indulge in treatment, but even he expresses ambivalence. When he receives his defibrillator, one of medicine's modern marvels, he muses that the "word when he first heard it pronounced by his cardiologist was unknown to him and sounded, innocuously enough, as if it had something to do with the gear system of a bicycle" (99).

Rabbit exudes ambivalence throughout. His friend's description of the bypass procedure does not help: “"To get at your heart,' he tells Rabbit, 'they split your whole rib cage open. They crack you open like a coconut. And they pull the best veins they can find out of your upper leg. So when you come out of it your groin's killing you as well as your chest'” (Updike 1990, 62). Even after his heart attack, Rabbit cannot take treatment seriously. He describes the surgery simply as " plumbing with a plastic pipe"” (165). He consents to angioplasty, but he is not impressed by the medical technology. Instead, he describes the experience as being violated, like a woman being penetrated or "queers being buggered" (273). His angina ultimately returns, but he refuses bypass surgery: "The balloon was bad enough" (396).

\section{Mechanization and Meaning}

Ever since Harvey described the heart as a pump, physicians have articulated mechanical visions of the heart that try to reduce its mysteries and suggest that they can achieve control over it. Mechanical 
metaphors of the heart show up early in fiction, even in Poe. In "The Tell-Tale Heart," he twice compares the sound made by the old man's heart to the sound "such as a watch makes when enveloped in cotton" $(181,191)$. With the same fascination, Roth's narrator revels in the mechanical details of heart disease and cardiac therapeutics. During his quintuple bypass, he was

connected to a heart-lung machine that pumped his blood and breathed for him. The doctors gave him five grafts, and he emerged from the surgery with a long wound down the center of his chest and another extending from his groin to his right ankle - it was from his leg that he had removed the vein from which all but one of the grafts were fashioned. (Roth 2006, 44)

Despite the concrete detail of these procedures, or perhaps because of it, the procedures stop feeling real to Roth's narrator. He dissociates during his angioplasty: "From the table he could watch the catheter being wiggled up into the coronary artery - he was under the lightest sedation and able to follow the whole procedure on the monitor as though his body were somebody else's" (72). Mechanistic narratives prove inadequate to render the experience, though. When the narrator receives the defibrillator, he interrupts an account of the anatomy of the procedure with a metaphor that anthropomorphizes the device. He describes it as "lodged beneath the skin of his upper chest, a few inches from his left shoulder, with its wire leads attached to his vulnerable heart, ready to administer a shock to correct his heartbeat—and confuse death — if it became perilously irregular" (75). These explanations alone, despite impressively biomedical detail, cannot satisfy Roth's goal of conveying the meaning and experience of CAD. Ultimately, he resorts to metaphor and anthropomorphisms (“confuse death").

If Roth's narrator revels in the technical details of what his doctors did to him, Updike's narrator cannot abide them. When Rabbit discusses angioplasty and bypass surgery with his doctor, he is repulsed by the details:

The idea of a catheter being inserted at the top of his right leg, and being pushed along steered with a little flexible tip like some eyeless worm you find wriggling out of an apple where you just bit, is deeply repugnant to him, though not as much so as being frozen half to death and sawed open and your blood run through some complicated machine while they sew a slippery warm 
piece of your leg vein to the surface of your trembling poor cowering heart. (Updike 1990, 269) The whole process seems like something out of Frankenstein. How can life be reduced to these mounds of flesh? "Harry has trouble believing how his life is tied to all this mechanics" (270). His doctors engage in the dialogue of metaphor and colorfully describe the difference between angioplasty and bypass surgery as "the difference between scrubbing out your toilet bowl with a long brush and actually replacing the pipes" (285). In the end, however, it is a sense of powerlessness that motivates him to accept his doctor's recommendation for angioplasty: “'I mean, they've got you by the balls. You're scared, and what else is there?"” (287)

Rabbit responds to his plight with his own analogies. He describes his angina as "a little playful burning like a child flirting with a lit match" (49), and it makes him think about what happens inside his body, something he does not want to do: "His insides are like the sea to him, dark and wet and full of things he doesn't want to think about" (113). Watching his own catheterization, he is appalled: “The mechanically precise dark ghost of the catheter is the worm of death within him. Godless technology is fucking the pulsing wet tubes we inherited from squid, the boneless sea-cunts" (274). Amid all the precise language and technical detail of medical science, Rabbit needs to recast the narrative through the perverse language of his sexualized fantasies.

By the late 20th century, cardiac pathophysiology and cardiac science had come together to produce a precise understanding of the heart and its dysfunction. This amalgam allowed doctors, patients, and fictional characters to fetishize the science and to intellectualize their suffering in a language of facts, figures, and technical details. Yet this construct remains artistically inadequate. Narrators demonstrate both the instability of technical metaphors and the emotional valences of heart disease. Despite the temptations of technical details, cardiac disease and medicine maintain their emotional meanings. No matter how well understood the heart is, and no matter how dramatic medical interventions are, the unreality of the experience for narrators forces them to reply through evocative metaphors, perhaps none more lurid that Rabbit's artery-fucking catheters. The technical details do not do justice to the experience of disease, and metaphor remains essential. 
Decades have passed since Sontag declared in Illness as Metaphor (1978) that "the healthiest way of being ill—is one most purified of, most resistant to, metaphoric thinking" (3). She sought to shed light on the ways that metaphor can be detrimental to a patient's sense of health and self and to open our eyes to the depth of meaning behind all-too-familiar words. Ten years after Illness as Metaphor, Sontag wrote AIDS and Its Metaphors (1989), in which she described this earlier passage as "a brief, hectic flourish of metaphor, in mock-exorcism of the seductiveness of metaphoric thinking" (93). She even affirms the ubiquity of metaphors: "Of course, one cannot think without metaphors. But . . s some metaphors we might well abstain from or try to retire" (93). Just as Anatole Broyard rejected Sontag's call, so do the characters and narratives in American fiction. Even those writers who are particularly well-versed in the latest heart disease pathophysiology and treatment, like Roth and Updike, present metaphor as an essential device for conveying the experience and meaning of disease to their audiences. As we have shown, these meanings arise from a complex mix of evolving knowledge of disease processes as well as current cultural, gender, and racial biases. But medical advances that have become popularized since Sontag's writing, despite impressive explanatory power, have not brought us closer to metaphor-free illnesses. Because of the limited ability of the biomedical narrative to convey the full meanings of disease and treatments, doctors and patients need to communicate through the nuanced and rich possibilities of metaphor. There are certainly inherent dangers in applying simplistic metaphors that can mislead patients and doctors, something too common in cardiology and cardiac surgery. The answer, though, cannot be to erase metaphor, or the narratives that motivate them. Instead, caregivers and patients must learn to recognize, interpret, and act on them.

\section{References}

Alberti, Fay Bound. 2010. Matters of the Heart: History, Medicine, and Emotion. Oxford: Oxford University Press.

Angus, Lynne, and Jeffrey Scott Mio. 2011. “At the 'Heart of the Matter': Understanding the Importance of Emotion-Focused Metaphors in Patient Illness Narratives. Genre 44 (3): 349-62. 
Aronowitz, Robert A. 1998. Making Sense of Illness: Science, Society, and Disease. Cambridge: Cambridge University Press.

Belling, Catherine. 2011. "Depth Perception.” Genre 44 (3): 239-62.

Binks, Andrew P., et al. 2002. “"Tightness' Sensation of Asthma Does Not Arise from the Work of Breathing." Am J Respir Crit Care Med 165 (1): 78-82.

Blair, Kristie. 2006. Victorian Poetry and the Culture of the Heart. Oxford: Oxford University Press. Blakeslee, A. 1966. "Want to Kill Husband? Try Atherosclerosis!” Youngstown Vindicator, March 6. Broyard, Anatole. 1992. Intoxicated by My Illness, and Other Writings on Life and Death. New York: Fawcett Columbine.

Cather, Willa. 1928. “Neighbour Rosicky.” In Obscure Destinies. New York: Vintage, 1974.

Charon, Rita. 2006. Narrative Medicine: Honoring the Stories of Illness. New York: Oxford University Press.

Chopin, Kate. 1894. “The Story of an Hour.” In The Awakening and Selected Stories of Kate Chopin. New York: New American Library, 1976.

Duffin, Jacalyn. 2002. Lovers and Livers: Disease Concepts in History. Toronto: University of Toronto Press.

Dylan, Bob. 1965. “Desolation Row.” Highway 61 Revisited. Columbia Records, B00026WU82, 1965, compact disc.

Effler, Donald B. 1968. “Surgery for Coronary Disease.” Sci Am 219: 36-43.

Engel, G.L. 1977. “The Need for a New Medical Model: A Challenge for Biomedicine.” Science 196: $129-36$.

Erickson, Robert. 1997. The Language of the Heart, 1600-1750. Philadelphia: University of Pennsylvania Press.

Fallon, Cara Kiernan. 2014. "How Different Are Women? Heart Disease, Gender, and the Boundaries of Women's Health." Paper presented at the 5th annual Workshop on the History of Cardiovascular Disease, Columbia University, New York, June 20, 2014. 
Fuks, Abraham, et al. 2011. "Narratives, Metaphors, and the Clinical Relationship." Genre 44 (3): 30114.

Goff, Sarah L., et al. 2014. "How Cardiologists Present the Benefits of Percutaneous Coronary Interventions to Patients with Stable Angina: A Qualitative Analysis.” JAMA Intern Med 174 (10): 1614-21. doi:10.1001/jamainternmed.2014.3328.

Good, Byron J. 1994. Medicine, Rationality, and Experience: An Anthropological Perspective. Cambridge: Cambridge University Press.

Groopman, Jerome. 2005. The Anatomy of Hope: How People Prevail in the Face of Illness. New York: Random House.

Hanne, Michael. 1999. "Getting to Know the Neighbours: When Plot Meets Knot.” Can Rev Comp Lit 26 (1): 35-50.

Hanne, Michael. 2011. “The Binocular Vision Project: An Introduction.” Genre 44 (3): 223-37.

Harvey, William. 1628. An Anatomical Disputation Concerning the Movement of the Heart and the Blood in Living Creatures. Trans. Gweneth Whitteridge. Oxford: Blackwell, 1976.

Hillman, James. 1981. “The Thought of the Heart.” In Eranos Lectures 2. Dallas: Spring.

Holmes, Martha Stoddard. 2004. Fictions of Affliction: Physical Disability in Victorian Culture. Ann Arbor: University of Michigan Press.

James, Henry. 1897. "The Turn of the Screw." In The Turn of the Screw and Other Short Fiction. New York: Bantam, 1983.

James, Henry. 1902. Wings of the Dove. New York: Penguin, 2008.

James, Henry. 1981. The Notebooks of Henry James, ed. F. O. Matthiessen and Kenneth B. Murdock. Chicago: University of Chicago Press.

Joel, Billy. 1977. “Movin' Out.” The Stranger. Columbia Records, CK 69384, 1977, compact disc.

Jones, David S. 2013. Broken Hearts: The Tangled History of Cardiac Care.Baltimore: Johns Hopkins University Press.

[AU: Not cited in text. OK to delete? SR]Jones, Thom. 1995. "Ooh Baby Baby.” In Cold Snap. New 
York: Little, Brown.

Lahiri, Jumpa. 2003. The Namesake. Boston: Houghton Mifflin.

Lakoff, George, and Mark Johnson. 1980. Metaphors We Live By. Chicago: University of Chicago Press.

Lin, Grace A., and R. Adams Dudley. 2014. "Fighting the 'Oculostenotic Reflex." JAMA Intern Med 174

(10): 1621-22. doi: 10.1001/jamainternmed.2014.164.

Literature, Arts, and Medicine Database. 1993-2015. Ed. Lucy Bruell. New York: New York University. http://litmed.med.nyu.edu/Main?action=new.

Martin, Emily. 1987. Woman in the Body: A Cultural Analysis of Reproduction. Boston: Beacon Press.

Martin, Emily. 1994. Flexible Bodies: Tracking Immunity in American Culture from the Days of Polio to the Age of AIDS. Boston: Beacon.

Master, Arthur M., Simon Dack, and Harry L. Jaffe. 1939. “Activities Associated with the Onset of Acute Coronary Artery Occlusion.” Am Heart J 18 (4): 434-43.

Mercer, Caroline G., and Sarah D. Wangensteen. 1985. “'Consumption, Heart Disease, or Whatever': Chlorosis, a Heroine's Illness in The Wings of the Dove." J Hist Med Allied Sci 40 (3): 259-85.

Mount Sinai Hospital. 2010. Advertisement. "Ironic that a Plumber Came to Us to Help Him Remove a Clog.” NY Times Mag, April 17, back cover. [AU: Please confirm date. SR]

Moy, Marilyn L., et al. 1998. "Language of Dyspnea in Assessment of Patients with Acute Asthma Treated with Nebulized Albuterol.” Am J Respir Crit Care Med 158 (3): 749-53.

Nabokov, Vladimir. 1955. Lolita. New York: Vintage, 1997.

Neuman, Yair. 2005. “"Meaning-Making’ in Language and Biology.” Perspect Biol Med 48 (3): 317-27.

Nikola-Lisa, W. 1998. “John Henry: then and now.” Afr Am Rev 32 (1): 51-56.

Osler, William. 1892. Principles and Practice of Medicine. New York: D. Appleton.

Osler, William. 1910. “Angina Pectoris.” Lancet 1: 697-701.

Poe, Edgar Allen. 1843. “The Tell-Tale Heart.” In The Portable Edgar Allan Poe, ed. J. Gerald Kennedy, 187-91. New York: Penguin.

Robinson, Marilynne. 2004. Gilead. New York: Farrar, Straus and Giroux. 
Rosenberg, Charles E. 1998. "Pathologies of Progress: The Idea of Civilization as Risk." Bull Hist Med 72 (4): $714-30$.

Roth, Philip. 1991. Patrimony. New York: Simon \& Schuster.

Roth, Philip. 2006. Everyman. New York: Vintage.

Rothberg, Michael B., et al. 2014. "The Effect of Information Presentation on Beliefs About the Benefits of Elective Percutaneous Coronary Intervention.” JAMA Intern Med 174 (10): 1623-29. doi: 10.1001/jamainternmed.2014.3331.

Sanghavi, Darshak. 2007. "Plumber's Butt? The Right and Wrong Way to Think about Heart Attacks." Slate, May 8. http://www.slate.com/articles/health_and_science/medical_examiner/2007/05/plumbers_butt.html

Schank, R. 1990. Tell Me a Story: A New Look at Real and Artificial Memory. New York: Scribner's. Schleifer, Ronald, and Jerry Vannatta. 2011. "The Chief Concern of Medicine: Narrative, Phronesis, and the History of Present Illness." Genre 44 (3): 335-47.

Sepucha, Karen, and Albert G. Mulley. 2009. “A Perspective on the Patient’s Role in Treatment Decisions." Med Care Res Rev 66 (1): 53S-74S.

Sontag, Susan. 1978. Illness as Metaphor. In Illness as Metaphor and AIDS and Its Metaphors. New York: Picador, 1990.

Sontag, Susan. 1989. AIDS and Its Metaphors. In Illness as Metaphor and AIDS and Its Metaphors. New York: Picador, 1990.

Sopory, Pradeep. 2005. "Metaphor in Formative Evaluation and Message Design: An Application to Relationships and Alcohol Use." Health Commun 17: 149-72.

Sopory, Pradeep, and James Price Dillard. 2002. “The Persuasive Effects of Metaphor: A MetaAnalysis." Human Commun Res 28 (3): 382-419.

Spodick, David. 1978. “Controlled Clinical Trials of Cardiac Surgery: What Happens Next Time?” Cardiovasc Med 3: 871-876. 
Springsteen, Bruce. 2006. "John Henry.” We Shall Overcome, Columbia Records, BSPCD024, 2006, compact disc.

Updike, John. 1990. Rabbit at Rest. New York: Knopf. 